\title{
Academic Freedom and Tenure: The University of Illinois
}

\section{Part I. Report of the Ad Hoc Committee}

Dr. Leo F. Koch, Assistant Professor of Biology in the Division of General Studies at the University of Illinois, Urbana, was suspended from his academic duties on April 7, 1960, by President David D. Henry because of a letter written by Professor Koch and published in The Daily Illini, the campus paper, on March 18, 1960. On June 14,1960, the Board of Trustees of the University ordered that Professor Koch be discharged and that his contract, which ran until August 31, 1961, be terminated as of the end of the current academic year,

\footnotetext{
${ }^{1}$ The text of this report was written in the first instance by the members of the ad boc investigating committee. In accordance with Association practice, the text was then submitted for consideration by the Association's standing Committee on Academic Freedom and Tenure (Committee A), to Professor Koch and to the Administration of the University of Illinois. In the light of comments and suggestions received, and with the editorial assistance of the Association staff, the report has been revised for publication. The reply of the Administration offered several corrections on matters it stated were not involved in Professor Koch's then pending appeal in litigation he had instituted against the University; it was accompanied also by preliminary observations of considerable length, which it authorized to be released to the aci boc committee and Committee A, which President Henry had received from the University's legal counsel after the latter's review of the draft text. The University, however, made clear that because of the pending appeal, it was of the view that adequate institutional comment on the report could not be accomplished and that accordingly it was constrained to defer formulation and presentation of a formal public statement of University position on the report until an appropriate later time. Following affirmance by the Illinois Appellate Court of the trial court decision, the Association again made inquiry of the Administration; the reply received called attention to the fact that Professor Koch was still in a position either to file a request for leave to appeal the matter to the Illinois Supreme Court or a petition for a writ of certiorari to the United States Supreme Court. Further communications between the Association and the Administration ensued, but did not result in receipt of any further comments from the University on the content of the report. The Association has concluded that in view of the present posture of the litigation and the focus, in any event, of the report on academic rather than legal judgments, it is appropriate to publish this report.

Immediately following this report will be found: (1) a separate statement by the ad boc committee on "academic responsibility," and (2) comments on "academic responsibility" by individual members of Committee $\mathrm{A}$.
}

that is, on August 31, 1960. On complaint of Professor Koch and the University of Illinois Chapter of the Association that the suspension, discharge and termination of contract constituted a violation of academic freedom, the General Secretary appointed the undersigned committee to investigate conditions of academic freedom and tenure at the University of Illinois, with particular reference to the case of Professor Koch.

The basic documents in the case were made available to the committee and on May 7, 8, and 9, 1961, the committee visited the campus of the University of Illinois at Urbana. The committee received full courtesy and cooperation from the University authorities and all others concerned. It interviewed all the chief participants in the Koch matter, with the exception of Professor Koch himself, who was in California. On June 2, two members of the committee, Professors Butts and Emerson, interviewed Professor Koch in Washington, D. C.

\section{Statement of Facts in the Koch Case}

The essential facts in the Koch case are matters of written record and are not in dispute. Our summary below is based upon this documentary material, supplemented by certain additional facts obtained in our investigation.

\section{Background of Professor Koch}

Professor Koch received the degree of Bachelor of Science in 1941 from the University of California at Berkeley and, following service with the armed forces during the war, obtained a master's degree in 1948 and a Ph.D. in 1950, both in botany, from the University of Michigan. After teaching at Bakersfield College and Tulane University from 1951 to 1955 he was appointed Assistant Professor of Biology in the Division of General Studies at the University of Illinois and began his teaching duties there in September, 1955. In 1957, the University of Illinois renewed his contract for two years. The contract was renewed again in 1959, but Professor Koch was notified that this appointment was a terminal 
one and would not be continued after the contract expired on August 31, 1961. Inasmuch as the charges against Professor Koch and the subsequent action taken by the University were predicated entirely upon the letter of March 18, 1960, the bases of the decision to give Professor Koch a terminal appointment are not relevant to the issues in this case and were not inquired into by the committee.

\section{Publication of the Letter of March 18}

On March 16, 1960, The Daily Illini published an article by two students entitled "Sex Ritualized." This article described scenes at a sorority house, a little past midnight, of couples "smooching and now and then mumbling passionately"; discussed the social pressures which require girls on dates to stay out until the curfew hour of one o'clock arrives; decried the fact that on campus dates men were not concerned with a girl "as a living individual," but "as a simple female sex unit"; and concluded:

Haven't our male-female relations on campus, in general, stultified into a predetermined ritual? It is our opinion that they have, and we think that nearly every student has ample evidence at hand to show this to be the case. We write this article because most students do not seem to recognize the obvious. They cannot recognize reality because they do not want to recognize reality. They fear it. People fear and seem incapable of opening their souls to one another-especially to one of the opposite sex!

Professor Koch's letter, written in response to the above article, was published on March 18. Its full text is as follows:

To the Editor:

You have made a great show of liberalism in racial problems whose center of physical and emotional disturbance is a safe, 1,000 miles away. I will be interested to see how your social conscience operates with a problem which strikes very close to home, here on campus.

The problem is broached by Dick Hutchison and Dan Bures in their article, "Sex Ritualized" (16 March) under the heading, "Off the Cuff" on your editorial page.

Hutchison and Bures are to be commended for their courage in candidly discussing the sexual problems of college students, even if only with narrow-minded, if not entirely ignorant, perspective.

Their discussion omits entirely any reference to the social meleu [sic] which compels healthy, sexually mature human animals into such addictions (of which masturbation is likely the least objectionable) to unhealthy and degenerative practices.

The first hazard encountered by the frank discussion in public of sexual problems is the widespread moralistic attitude that where there is smoke, there is fire. Any one who insists on speaking about sex in public, say the orthodox moralists, (unless it is condemned soundly) must be a sexual deviate (a Queer) in their orthodox view.

The second, and by far the more important, hazard is that a public discussion of sex will offend the religious feelings of the leaders of our religious institutions. These people feel that youngsters should remain ignorant of sex for fear that knowledge of it will lead to temptation and $\sin$

Hence we have the widespread crusades against obscenity which are so popular among prudes and puritanical old-maids. Bachelors are known to be immune to this disease inasmuch as they are the favored sex in a double standard of morality which accepts as respectable premarital sexual experience for men but not for women. This occasions some difficulty as most men are heterosexually inclined.

Thus we come to the crux of the problem which is not even hinted at by Hutchison and Bures. Their article would lead a casual reader [to believe] that the evils portrayed by them are due only to the depravity of the individuals they observed, whereas, in fact, the heavy load of blame should fall on the depraved society which reared them.

I submit that the events described by Hutchison and Bures are merely symptoms of a serious social malaise which is caused primarily by the hypocritical and downright inhumane moral standards engendered by a Christian code of ethics which was already decrepit in the days of Queen Victoria.

College students, when faced with this outrageously ignorant code of morality, would seem to me, to be acting with remarkable decorum, and surprising meekness, if they do no more than neck at their social functions.

Perhaps it would be nearer to the truth to say that such meek and very frustrating, no doubt, behavior indicates an extreme degree of brainwashing by our religious and civil authorities in the name of virtue and purity, to the point where the students have become psychologically inhibited from satisfying their needs in more obvious and healthy ways.

With modern contraceptives and medical advice readily available at the nearest drugstore, or at least a family physician, there is no valid reason why sexual intercourse should not be condoned among those sufficiently mature to engage in it without social consequences and without violating their own codes of morality and ethics.

A mutually satisfactory sexual experience would eliminate the need for many hours of frustrating petting and lead to much happier and longer lasting marriages among our younger men and women.

\section{Leo F. Koch \\ Assistant Professor of Biology}

Members of the faculty frequently write letters to The Daily Illini or to other newspapers. Most often these

\footnotetext{
"The letter as published was headed, "Advice on Sex." This caption was inserted by the editor of The Daily Illini without the knowledge of Professor Koch, and was not considered by the University officials as part of the letter.
} 
letters are signed by the writer without designation of his faculty title, but it is not uncommon for the author to identify himself by adding his faculty title to his name.

\section{Applicable University Regulations}

The University Statutes provide that the tenure of any faculty member whether appointed for an indefinite or a definite term, may be terminated by retirement, resignation, or "discharge for cause" [Sec. 38(c)]. The latter term is defined as follows in Section 38(d):

(d) Cause for discharge shall consist of conduct seriously prejudicial to the University through deliberate infraction of law or commonly accepted standards of morality, neglect of duty, inefficiency or incompetency. The enumeration of causes for discharge shall not be deemed exclusive, and the Board of Trustees reserves the power to discharge for other causes, but it is to be distinctly understood that this power will be exercised only under exceptional circumstances and then only for conduct which is clearly prejudicial to the best interests of the University.

\section{Section 39 of the statutes provides in part:}

Sec. 39. (a) It is the policy of the University to maintain and encourage full freedom, within the law, of inquiry, discourse, teaching, research, and publication and to protect any member of the academic staff against influences, from within or without the University, which would restrict him in the exercise of these freedoms in his area of scholarly interest....

(b) In his role as citizen, the faculty member has the same freedoms as other citizens, without institutional censorship or discipline, although he should be mindful that accuracy, forthrightness, and dignity befit his association with the University and his position as a man of learning.

(c) These freedoms do not include the right to advocate the overthrow of our constitutional form of government by force or violence. ...

The procedure for termination is established by Section $38(e)$ and $(f)$ :

(e) An appointee on definite tenure shall not be removed before the expiration of his term of service, nor shall an appointee on indefinite tenure be removed, without in either instance first having been presented with a written statement of the charges against him, which shall be sufficiently specific reasonably to inform him of their nature and to enable him to present his defense thereto. Charges shall be preferred by the President, or on his authority, and shall be filed with the Secretary of the Board of Trustees. A copy of the charges shall be transmitted to the appointee either personally or shall be mailed to the appointee at his last known post-office address by registered mail within 15 days after they have been preferred. Within 15 days after such service of a copy of the charges, the appointee may file with the Secretary of the Board a written request for a hearing before the Board of Trustees. Notice of the time and place of the hearing, which shall be not less than 20 days after the date of the appointee's request, shall be served upon the appointee either personally or by registered mail. The date of the hearing shall be no less than 15 days from the date of the receipt of the notice of hearing, by the appointee. The appointee shall have the right to appear at the hearing, with counsel, if he desires, to reply to the charges and to present evidence in his behalf. The Board shall not be bound by formal or technical rules of evidence in hearing and deciding the case. Prior to the preferment of charges, or while charges are pending, the appointee may be suspended by the President pending final decision of the Board upon the charges. . . .

(f) Any member of the faculty of the University, who claims that termination of his services would violate principles of academic freedom, shall have the right to a hearing hefore the Committee on Academic Freedom of the appropriate Senate prior to a hearing, if any, before the Board of Trustees. Such hearings shall be conducted in accordance with established rules of procedure. The Committee shall make findings of fact and recommendations to the President of the University. The several Committees may, from time to time, establish their own rules of procedure.

Events from March 18 to President Henry's Letter of April 7

The publication of Professor Koch's letter on Friday, March 18, created an immediate stir at the University and beyond. According to Royden Dangerfield, Associate Provost and Dean of Administration, the letter reached President Henry on the day of publication and President Henry asked him (Dangerfield) to look into the matter. The letter was widely discussed on the campus and in the local press. Under date of March 25, the Rev. Ira H. Latimer, of the Institute of Economic Policy, Chicago, and a member of the University of Illinois Dads' Association, sent a four-page communication to the parents of a substantial number of women students. In this letter Mr. Latimer reprinted the Koch letter and denounced it as "an audacious attempt to subvert the religious and moral foundations of America" which followed the "standard operating procedure of the Communist conspiracy." As a result of the Latimer communication and the other publicity, the University authorities received numerous letters of protest.

Professor Koch's immediate superiors on the faculty were Professor Otto E. Kugler, Chairman of Biological Science in the Division of General Studies, and Professor James M. McCrimmon, Head of the Division of General Studies. Professor McCrimmon, who was on sabbatical leave, stated that the Koch letter was called to his attention on the Friday of publication by his secretary and members of the DGS staff; that at first he decided to do nothing about it but "waited to see if it would blow 
over." At the beginning of the following week, however, Professor McCrimmon was called by Associate Provost Dangerfield and asked to come in for a conference with him and Lyle H. Lanier, then Dean of the College of Liberal Arts and Sciences. At this conference, according to Professor McCrimmon, Associate Provost Dangerfield stated that President Henry was much disturbed about the letter and wanted them to make recommendations to him as to what action would be proper. The matter was discussed and three possible courses of action were outlined and reported to President Henry: (1) reprimand, (2) relief from classes, and (3) dismissal. Professor McCrimmon stated that no definite recommendation was made at this meeting, that he had no knowledge of what official action would be taken, and that he understood that action would be taken at the College level.

On March 25 Professor McCrimmon, apparently on his own initiative, called in Professor Koch for an interview with himself and Professor Kugler. In a subsequent memorandum summarizing the meeting, Professor McCrimmon said, "I told Koch that I had asked for the meeting to tell him what his colleagues in DGS and I, personally, thought of his recent letter in the Illini and that I had put these thoughts into a letter which he would get as soon as it could be typed and delivered." The meeting lasted 25 minutes. Professor McCrimmon stated his objections to the Koch letter, and Professor Koch made a brief reply. Professor McCrimmon also informed Professor Koch that "the President and Dean are concerned," but did not state whether or not further action would be taken. On the following day Professor McCrimmon mailed his letter of reprimand to Professor Koch.

The next action was a meeting of the Executive Committee of the College of Liberal Arts and Sciences on March 28. This Committee is elected by all members of the faculty of the College having the rank of instructor or higher; at that time it consisted of the Dean, the Associate Dean and five other members, of whom four were Department Heads and one was an Associate Department Head. No final decision was reached on March 28 and a second meeting of the Executive Committee was held on April 6. At neither meeting did the Executive Committee call in or communicate with Professor Koch. Nor did it consult with Professors McCrimmon or Kugler, although memoranda from them summarizing their interview with Professor Koch, and the letter of reprimand, were before the Committee at its second meeting.

On April 7, Dean Lanier, as Chairman of the Executive Committee, reported by letter to President Henry the recommendations of the Committee. Dean Lanier's letter summarized the McCrimmon-Kugler memoranda and the letter of reprimand, and enclosed copies of these documents. It went on:
The Committee's attention ... was directed primarily to the question of whether or not Dr. Koch's published letter constituted a breach of academic responsibility so serious as to justify a recommendation that he be relieved of his University duties. It was voted at the meeting on April 6 to make such a recommendation (one member did not concur).

It was voted further to recommend that Dr. Koch's salary be continued for the remainder of the present academic year. Three of the six members of the Committee-including myself-felt that some kind of additional financial settlement should be arranged to cover the second year of his contract-not because of any legal obligation to do so in the circumstances, but primarily out of consideration for the economic jeopardy in which Dr. Koch's irresponsible action has placed his family.

On the same day, April 7, President Henry addressed the following letter to Dean Lanier:

I have your memorandum of April 7 reporting the deliberations of the Executive Committee of the College of Liberal Arts and Sciences concerning Assistant Professor Leo F. Koch. You report that Professor Koch's letter published in the Daily Illini on March 18, 1960 raised serious doubt as to his sense of academic responsibility and hence as to his further usefulness as a teacher in the College of Liberal Arts and Sciences.

I note that the Head of Professor Koch's Department, Professor James M. McCrimmon, in substance informed Professor Koch on March 25 that his letter constituted a breach of professional responsibility and in conference with Professor Koch condemned both the tone and much of the content of the letter.

I note further that it is the Executive Committee's view that Professor Koch's published letter constitutes a breach of academic responsibility so serious as to justify his being relieved of his University duties.

This memorandum is to record my concurrence in the recommendation of the Committee and to request you to relieve Professor Koch of his duties immediately. His appointment will be terminated at the University at the end of the current academic year.

With you, I consider Professor Koch's letter a grave breach of academic responsibility. The views expressed are offensive and repugnant, contrary to commonly accepted standards of morality and their public espousal may be interpreted as encouragement of immoral behavior. It is clear that Mr. Koch's conduct has been prejudicial to the best interests of the University.

I request that you and Professor McCrimmon communicate this decision to Professor Koch.

David D. Henry President

cc: Professor Leo F. Koch

Professor James M. McCrimmon

Members of the Executive Committee, College of Liberal Arts and Sciences

Provost Gordon N. Ray

Mr. A. J. Janata, Secretary, Board of Trustees

Members of the Board of Trustees 
President Henry's letter of April 7 was released to the public with an accompanying press release. Copies were sent to the members of the Board of Trustees.

It will be noted that under Section 38(e) of the University Statutes, quoted above, President Henry had no authority to discharge Professor Koch or terminate his contract, his power being limited to filing charges and suspension of the appointee "pending final decision of the Board upon the charges." President Henry explained the flat statement in his letter-that Professor Koch's "appointment will be terminated at the University at the end of the current academic year" - on the ground that persons connected with the University knew he had no power to discharge and would understand that his letter was only a recommendation to the Board of Trustees. The investigating committee for the Association has encountered a variety of recollection on the question whether President Henry was advised that he had no power to discharge a faculty member (1) while the April 7 letter was in draft form, or (2) after it had been sent to Professor Koch. In any event it seems clear that the letter was interpreted by the public, and very likely by substantial segments of the University, as constituting a final discharge. President Henry made no effort to clarify the situation by subsequent public statement.

Hearing and Decision of the Senate Committee on Academic Freedom

On April 8, after receiving a copy of President Henry's letter to Dean Lanier, Professor Koch asked for a hearing before the Senate Committee on Academic Freedom of the Urbana-Champaign campus. The Senate of the Urbana-Champaign campus is composed of all faculty members on that campus holding full professorial rank, the deans of the colleges and directors of the schools and institutes, heads of departments, and certain other academic and administrative personnel; a few persons below the rank of full professor are members by virtue of their election to membership on Senate Committees. The Academic Freedom Committee is elected annually by the Senate. The Committee held its hearings on April 18 and 19. The charges against Professor Koch consisted of President Henry's letter of April 7, which was construed by the Committee to incorporate by reference Dean Lanier's letter of April 7 and its accompanying documents. Witnesses before the Committee were Professor Koch, Dean Lanier, and President Henry, who were heard separately and in private.

The Senate Committee made its report on May 13. Its conclusions were:

(1) A faculty member has the right to express views on sexual behavior, as on other subjects, which may be considered "offensive and repugnant," "contrary to commonly accepted standards of morality," and to criticize prevailing views.
(2) Professor Koch committed a breach of academic responsibility, "not because he publicly expressed controversial views on sexual mores, but because of the way in which he expressed them, and because of the circumstances under which he caused his letter to be published in the Daily Illini."

(3) The administrative officers of the University "acted in several respects contrary to the standards of proper procedure in dismissal cases" in that (a) the President exceeded his authority in announcing publicly that Professor Koch's contract would be terminated; (b) the University gave wide publicity to the charges; (c) Professor Koch did not receive a hearing prior to the recommendation for suspension and contract termination; and (d) the charges were formulated in a different manner in President Henry's letter than they were in Dean Lanier's letter. "While Professor Koch has not been denied his statutory rights to hearings before this committee and before the Board of Trustees, the foregoing procedural defects may well have prejudiced the final outcome of his case."

(4) "The publication of Professor Koch's letter has been prejudicial to the best interest of the University, in that it may have damaged the standing of the University in the eyes of many people in the State of Illinois; the administration therefore had a legitimate concern with this damage and valid reason for action to minimize it." But "strict application of this standard to justify discharge would discourage expression of unpopular views and thus seriously impair any meaningful academic freedom."

(5) The failure of the University to use proper procedure, President Henry's sweeping formulation of the charges, and the premature publicity given the charges "have been prejudicial to the standing of the University in the academic community in this country and abroad." "The discharge of an academic staff member for cause deemed as prejudicial to the best interests of the University because of adverse public reaction may alarm the academic community and cause even greater harm." Such damage should be avoided and, to the extent it has already occurred, "it, too, calls for remedial action."

(6) In the opinion of three members, "discharge would be so excessive a penalty as to constitute a violation of Professor Koch's academic freedom." In the opinion of three other members, Professor Koch's action was a sufficiently clear violation of academic responsibility to invalidate his claim to the protection of academic freedom, but that the general interests of academic freedom at this University would not be served by his "discharge."

On the basis of the above conclusions the Senate Committee recommended unanimously:

(1) That Professor Koch be reprimanded for his action and admonished to act in keeping with the dignity 
and responsibility of a scholar, but not be discharged.

(2) That the Statutes of the University of Illinois be revised so as to assure a faculty member that, in the case of a discharge action against him, definite fair procedures will be followed, in particular, on adequate opportunity to defend himself before a properly elected committee of his peers prior to any suspension, and, in any case, prior to a recommendation for discharge.

(3) That the University administrative officers clearly state that the University does not consider the expression of views, however contrary to prevailing opinions, as, in itself, a violation of academic responsibility, provided it is made in conformity with the legal and statutory restraints imposed on a faculty member as a citizen, a teacher, and a scholar.

The report of the Senate Committee was made available to the Board of Trustees and to Professor Koch and his counsel, but was not made public until the hearing of the Board of Trustees on June 14.

\section{Hearing and Decision of the Board of Trustees}

Professor Koch had, on April 11, requested a hearing before the Board of Trustees, and the Board, at its meeting on April 20, granted the request. Following the report of the Senate Committee on Academic Freedom, President Henry submitted to the Board of Trustees a. recommendation that it terminate Professor Koch's appointment at the end of the current academic year (i.e., August 31, 1960), but requested that the Board defer action on his recommendation until the hearing requested by Professor Koch had been held. The Board then fixed June 14,1960 , as the date of the hearing.

At the hearing before the Board, counsel for the University and counsel for Professor Koch joined in introducing a stipulation of facts, which consisted largely of a statement of events based upon the documents summarized above. Counsel for the University also offered in evidence the 1940 Statement of Principles on Academic Freedom and Tenure jointly adopted by the American Association of University Professors and the Association of American Colleges and a section of the "Code on Undergraduate Student Affairs of the University of Illinois" dealing with student discipline. These were admitted over the objection of counsel for Professor Koch. Counsel for the University likewise asked the Board to take administrative notice of certain "commonly accepted standards of morality which prevail in the community in which the Urbana-Champaign campus of the University of Illinois is located," which the Board did over objection. No other evidence was produced by either side. Professor Koch was present but did not testify. The Board then heard oral arguments from both sides.

At the close of the argument counsel for the University submitted a detailed statement of Suggested Findings and Conclusions. The Board then retired into executive session. It reconvened the public hearing approximately an hour later and, upon motion of one of its members, voted unanimously to adopt the findings and conclusions submitted by counsel for the University and to approve and adopt the recommendation of the President that Professor Koch's appointment and contract be terminated as of August 31, 1960.

The basic findings adopted by the Board of Trustees, in addition to those setting forth the course of events established by the documentary evidence, were as follows:

(1) That it was Professor Koch's "intention not only to condone sexual intercourse between students enrolled in and attending the University of Illinois who are not married to each other but that he also intended thereby to encourage and espouse such immoral conduct upon the part of such students."

(2) That Professor Koch's letter of March 18 "was not a reasoned statement, marshalling evidence in support of views held by him, but was one in which, through the use of overstatement and ridicule, he denounced society as depraved, condemned as inhumane and obsolete the widely accepted moral standards derived from the Christian code of ethics and the commonly accepted moral standards then prevailing in the community ... , and in which he castigated those who might disagree with his conclusions as outrageously ignorant; and . . . that the language of that letter was not in keeping with those standards of temperateness, dignity, and respect for the opinions of others which should characterize public expression by members of the faculty of the University of Illinois." It also found that the letter did not adhere to required standards of accuracy, and that Professor Koch had not made plain he was not writing as "a spokesman for the University."

(3) That Professor Koch's action in publishing the letter, "taken together with the language, tone, and contents of the letter, constituted a decidedly serious and reprehensible breach of the academic and professional responsibility owed by Assistant Professor Koch to the University of Illinois, which has caused great concern to the parents of students attending the University and to citizens of the State of Illinois as to the moral standards which prevail and are maintained at the University, which has been and is clearly prejudicial to the best interests of the University of Illinois and which has so seriously impaired his usefulness to the University that its best interests would clearly be further and seriously prejudiced by continuing to keep him in its employ."

(4) That Professor Koch "has been granted and has received all of the procedural rights and all rights to hearings granted him by the provisions of the University of Illinois Statutes in connection with this entire proceeding."

(5) That the action of President Henry in releasing to the press his letter of April 7 "was rendered desirable, appropriate, and proper in view of the publicity" Pro- 
fessor Koch's letter had received, and "also because of the desirability and necessity created thereby that the disavowal by the University administration to the views expressed by Assistant Professor Koch in his said letter reach and be made known to the citizens of the State of Illinois and the parents of students"; and that the release to the public press did not "operate to his prejudice in the consideration and disposition which this Board of Trustees is making of the charges preferred."

In its Conclusions the Board stated that the "tone, language, and content" of Professor Koch's letter were such that his publishing it "constituted a grave breach of his academic and professional responsibility and duty to the University of Illinois, the students attending the University, and the citizens of the State of Illinois." It went on to say:

We recognize that the limits of academic freedom cannot be defined by the test of conformity or nonconformity between views expressed by a member of the University's faculty and views, beliefs, and standards generally and commonly entertained and accepted. We believe that any responsible expression of views by the members of the faculty, even though unpopular and even, possibly, untenable, is in order. ...

We do not condemn Assistant Professor Koch's actions in issue here merely because he expressed in his letter views contrary to commonly accepted beliefs and standards. We condemn it because of the manner in which he expressed those views in his letter. We do not consider that letter as a "responsible" and proper expression of the views stated in it.

\section{Events after Board of Trustees Decision}

On July 15, 1960, a group of 229 members of the faculty on the Urbana-Champaign campus signed an Open Letter to the Board of Trustees. This letter stated, "The welfare of this University and its ability to fulfill its function as an institution of higher learning have been seriously impaired by the handling and disposition of the case of Professor Koch." It went on to make the following points:

(1) In the mind of the public as well as in the final statement of the Board of Trustees, a basic charge against Professor Koch is still that contained in President Henry's letter of April 7 -expression of opinions "offensive and repugnant" and "contrary to the commonly accepted standards of morality." These criteria are unacceptable as limits on a professor's freedom of expression.

(2) By failure to follow proper procedures "the case may have been so prejudiced that no fair hearing was possible."

(3) By largely rejecting the recommendations of the Champaign-Urbana Senate and its Committee on Academic Freedom the President and the Board have failed to show adequate recognition of the responsibility which the faculty must have for the conduct of its members.
The Open Letter concluded by urging the Board of Trustees "to give the faculty formal assurance: (1) that expression of opinion contrary to commonly accepted standards of morality is not considered cause for dismissal of a faculty member; (2) that the objectionable administrative procedures followed in the case of Professor Koch will not be condoned in the future; and (3) that the primary consideration in cases involving tenure be the recommendations of established faculty agencies."

The Open Letter was referred by the Board of Trustees to its Committee on General Policy. On September 21, 1960, this Committee submitted its report, which was adopted by the full Board. The report stated that the basic charge against Professor Koch "was not that he expressed ... views which were 'offensive and repugnant' and 'contrary to the commonly accepted standards of morality' but was that his actions in writing the letter and securing its publication constituted a decided and serious breach of the academic responsibility inherent in his University employment" as declared in the University Statutes and the 1940 Statement of Principles. The report went on to say:

We would not be justified in saying, wholly without qualification, "that expression of opinion contrary to commonly accepted standards of morality is not considered cause for dismissal of a faculty member." We do state that a responsible expression of such an opinion, made under proper circumstances and with due regard for the provisions of Sections 38 and 39 of the University Statutes, and for those of the above mentioned "Joint Statement of Principles on Academic Freedom and Tenure" would not be so considered by us. In determining whether such an expression of opinion is a "responsible" one, and has been so made, the occasion for, the circumstances surrounding, and media used in publicly expressing the opinion, and the tone, content, and purpose of the public expression of it must be given due consideration.

The report also defended the procedure followed in the case and stated, "We intend and stand ready to always accord due consideration, and substantial weight, to the opinions and recommendations of established faculty agencies in such cases," but that "final authority" rested with the Board. The report concluded:

The reputation of the University of Illinois for scholarship and for academic integrity, in teaching and research, will remain the continuing concern of this Board of Trustees. This Board will receive, and will seriously and carefully consider, suggestions for maintaining and strengthening that reputation. The statutes of the University provide for an orderly procedure whereby such suggestions may be submitted to us and brought to our attention.

Subsequently the Senate Committee on Academic Freedom prepared a series of proposed amendments to the 
University Statutes relating to academic freedom and tenure. These proposals include a revision of Section 38(d), dealing with cause for discharge, and establish detailed procedures in dismissal cases in lieu of the present provisions of Section 38(e) and (f). The proposals have been considered and adopted by the three Senates of the University of Illinois (at the three campuses). After further consideration by the Academic Freedom Committees of the three Senates and the University-wide Coordinating Council (a faculty group), it is believed that faculty agreement will be achieved. The amendments will then be transmitted to the Administration.

In March, 1961, counsel for Professor Koch filed a complaint in the Superior Court of Cook County alleging that the discharge constituted a breach of contract and a violation of constitutional rights, and seeking damages. The lower court dismissed the complaint, and the intermediate appellate court has affirmed. Further appeal is possible but appears not to have been made at the time these pages go to the printer.

\section{The Discharge: The Procedural Issues}

The case raises three major issues of procedure. These are whether academic due process was violated by (1) President Henry's letter of April 7; (2) a failure to state the charges with sufficient definiteness to enable Professor Koch to make his defense; and (3) a failure of the Board of Trustees to give sufficient weight to the findings and recommendations of the faculty, particularly the Senate Committee on Academic Freedom.

\section{A. President Henry's Letter of April 7}

President Henry's letter of April 7, quoted above, announced that Professor Koch's appointment "will be terminated at the University at the end of the current academic year." The letter was released to the public. As previously noted, President Henry had no authority to terminate Professor Koch's appointment but only to prefer charges and to suspend "pending final decision of the Board upon the charges." The issue is whether this public announcement that Professor Koch would be discharged, made before charges had been filed or heard, so prejudiced Professor Koch's case as to constitute a denial of academic due process.

The Board of Trustees found, as set forth previously, that Professor Koch had received all procedural rights; that the public release of President Henry's letter was appropriate because of the publicity which Professor Koch's letter had received and because of the necessity to disavow his views; and that the release did not operate to Professor Koch's prejudice in the disposition of the charges. The Report of the Committee on General Policy, adopted by the Board of Trustees, further declared that "ordinarily" the Board would not approve of publication of charges prior to hearing, but that in this case "exceptional circumstances" made it necessary and desirable. It also stated:

President Henry has been unjustly accused of usurping the authority vested solely in the Board of Trustees and attempting to terminate Dr. Koch's contract upon his own authority. While some language appearing in President Henry's letter of April 7, 1960, to Dean Lanier might be interpreted to lend some support to this charge, President Henry has made it plain in statements he has made to the Trustees ... that he intended that portion of his letter to constitute only a statement of his intention to submit a recommendation to the Board of Trustees that Dr. Koch's contract be terminated. . . . Both President Henry and Dean Lanier were thoroughly familiar with the provisions of the University Statutes and we are convinced that President Henry intended that portion of his letter to be, and that it was so understood by Dean Lanier. Moreover, President Henry has assured us that he did not expect or intend that we would be committed by that portion of the letter to terminate Dr. Koch's contract, and we certainly did not consider ourselves to be bound by it to take that action.

We do not feel that the Board's explanation fully meets the issue. In our view, the publication of President Henry's letter did seriously prejudice Professor Koch's case. While some members of the University administration and faculty undoubtedly realized that President Henry had no authority to decide the issue of discharge, the general public impression was given that the matter had been disposed of by the University. The investigating committee has already noted that President Henry made no effort to clarify the situation. The result was that a difficult burden was placed upon Professor Koch to reverse the tide rolling over him, and both the Senate Committee on Academic Freedom and the Board of Trustees were put in an embarrassing position where, as a practical matter, it would be difficult for them to decide on the basis of a clean slate.

We conclude, therefore, that President Henry's letter, with its ensuing publication, amounted to prejudgment of the issues, prior to charges and hearing, and thereby constituted a violation of academic due process.

\section{B. Sufficiency of the Charges}

President Henry's letter of April 7 was taken as a statement of the charges. While it was not clear from the letter, the Senate Committee on Academic Freedom interpreted the letter as incorporating by reference the letter of Dean Lanier to President Henry and its accompanying material, these documents thus also becoming part of the statement of charges. The Board of Trustees, although not making the point clear, seems to have accepted the Senate Committee's view.

The charges as thus formulated certainly lacked precision, clarity, and perhaps consistency. But in our view 
Professor Koch was not prejudiced thereby. At the hearing before the Senate Committee he addressed himself to all the issues under consideration. At no time did he or his counsel request a more specific statement of the charges. There is no indication from the record or our investigation that Professor Koch suffered from a lack of understanding or an opportunity to meet the issues upon which the case was decided. Consequently we find no violation of due academic procedure in the manner of stating the charges.

\section{Failure of Board of Trustees to Give Sufficient Weight to Faculty Position}

It is difficult to define with precision the weight that the governing board of a university should accord to the findings and recommendations of the faculty on issues of academic freedom. But the general principle is clear. Matters of "academic responsibility," as well as issues of competency and other issues of academic freedom, should rest primarily with the judgment of the academic group and that judgment should be overturned by the governing board only if it is plainly unreasonable. We do not think the University administration complied with this fundamental principle in this case.

We base this conclusion in part upon the fact that, as we read the Board of Trustees' decision, it fails to recognize the significance of the findings and recommendations of the Senate Committee on Academic Freedom. The Board states that the Senate Committee's "appraisal of [Professor Koch's] letter to The Daily Illini accords with ours"; it then goes on to say that "once it has been determined that Assistant Professor Koch's actions are not protected by his academic freedom, the question of what action should be taken against him because of his breach of his academic and professional responsibility and duty to the University is one which we have the responsibility, duty, and authority to determine." The Board thus conveys the impression that the Senate Committee on Academic Freedom reached the same conclusion as the Board, except on the subsidiary issue of what the form of discipline should be. Actually, the Senate Committee's conclusion was quite different from that of the Board. The Senate Committee did find a "breach of academic responsibility"; but it found only the kind or degree of breach that would justify a reprimand. The Board found a wholly different kind of breach, one that warranted a discharge. Thus the Board, for all practical purposes, ignored the essence of the Senate Committee's position.

Furthermore, in our view, the whole process leading to dismissal was conducted by the administrative authorities in isolation from the academic community, where the primary judgment should have rested. The first official action, other than Professor McCrimmon's reprimand, was taken by the Executive Committee of the College of Liberal Arts and Sciences, an elected body but one then consisting entirely of personnel at the departmenthead level and one not charged with consideration of academic freedom matters. This committee did not call in Professors McCrimmon or Kugler, or Professor Koch himself, though it did have the McCrimmon and Kugler memoranda before it. On the same day he received the Executive Committee's report, which split three to three on discharge without payment of salary for the second year of Professor Koch's contract, President Henry issued his letter which on its face appeared to dispose of the whole matter by dismissal. It was not until later, essentially when the matter was referred to the Senate Committee, that the course of procedure required by the Unversity Statutes began to be followed. Even then, the Board of Trustees failed to consider the nature of the breach of academic responsibility found by the Senate Committee. Our impression is that the process was guided administratively without sufficient opportunity for participation and regard for the views of the academic group in the University.

\section{Other Issues}

The committee considers it important to call attention to three other matters relating to academic freedom and tenure at the University of Illinois.

\section{A. Tenure}

Section 38 of the University of Illinois Statutes states:

(a) Unless otherwise provided in these Statutes (and in the absence of some special written agreement approved by the President of the University with the consent of the appointee) the tenure for the various members of the academic staff shall be as stated herein, except that first appointments or temporary appointments may be made for shorter periods.

(1) An appointment as professor or associate professor shall be for an indefinite term.

(2) An appointment as assistant professor, or to the administrative staff, shall be for a period not longer than two years from September 1 of the first year of the legislative biennium.

(3) Appointments to lower ranks shall be for not more than one year.

(b) The appointment of any person for a definite term does not carry any guarantee or implication that the Board of Trustees will renew the appointment at its termination, even though the appointee may have discharged his duties satisfactorily. Any appointment, if accepted, must be accepted with this stipulation.

It will be noted that the University Statutes set no limit for the number or total duration of nontenure appointments, which are given to assistant professors and instructors.

The 1940 Statement of Principles on Academic Freedom and Tenure provides:

Beginning with appointment to the rank of full-time instructor or a higher rank, the probationary period 
should not exceed seven years, including within this period full-time service in all institutions of higher education; but subject to the proviso that when, after a term of probationary service of more than three years in one or more institutions, a teacher is called to another institution it may be agreed in writing that his new appointment is for a probationary period of not more than four years, even though thereby the person's total probationary period in the academic profession is extended beyond the normal maximum of seven years. Notice should be given at least one year prior to the expiration of the probationary period if the teacher is not to be continued in service after the expiration of that period.

\section{B. Suspension}

Section 38(e) of the University of Illinois Statutes, as quoted previously, states:

Prior to the preferment of charges, or while charges are pending, the appointee may be suspended by the President pending final decision of the Board upon the charges.

The 1958 Statement on Procedural Standards in Faculty Dismissal Proceedings, prepared by a joint committee representing the Association of American Colleges and this Association as a guide in dismissal proceedings, provides:

Suspension of the faculty member during the proceedings involving him is justified only if immediate harm to himself or others is threatened by his continuance.

\section{Notice and Terminal Pay}

The University of Illinois Statutes seem to be silent on the question of payment, under an existing contract or otherwise, for persons dismissed for cause.

The 1940 Statement of Principles on Academic Freedom and Tenure states:

Teachers on continuous appointment who are dismissed for reasons not involving moral turpitude should receive their salaries for at least a year from the date of notification of dismissal whether or not they are continued in their duties at the institution.

The Investigating Committee notes these differences between the University of Illinois Statutes and the principles, procedures, and standards which the Association supports, in relation to certain matters of tenure, suspension, notice and terminal pay. It believes that the resolution of these differences is a matter of appropriate concern to the administrative officers and faculty members of the University of Illinois.

\section{Present Status of Academic Freedom at the University of Illinois}

It is the opinion of the committee that the Koch case has had serious repercussions on academic freedom at the
University of Illinois. The committee was not, of course, able to make an exhaustive investigation beyond the facts of the Koch case itself. To have ascertained sentiment among. a large and varied faculty would not have been an easy task, even if the committee had had the time and resources to undertake it. Such opinion as we did sound out was by no means unanimous.

Nevertheless, we think it fair to say that there is substantial concern over the question whether the University actually will permit untrammeled discussion of highly controversial issues, or whether freedom to express unpopular views will be seriously qualified by the test of "encouragement" and "academic responsibility." There is also serious concern over the procedure employed in the Koch case, particularly President Henry's precipitate action in announcing Professor Koch's discharge. The issues raised by the open letter signed by 229 faculty members have not been settled by the report of the Committee on General Policy. Among the lower ranks of the faculty there appears to be some reluctance to oppose openly the actions of the administration in the Koch matter, or generally to espouse unorthodox or deviant views in controversial areas.

We believe that an essential factor in restoring a freer atmosphere on the campus will be the outcome of present negotiations to revise the University Statutes dealing with academic freedom. If the substantive grounds for discipline can be narrowed and defined more precisely, and if the procedure can be clarified and stated more specifically, substantial progress should result. Moreover, as has been noted, attention should be given to deficiency in the regulations governing tenure, suspension, and length of notice in dismissal of tenure faculty when moral turpitude is not involved.

It would be our hope that, out of the Koch case, the University authorities will come to take a broader view of the function of a university and the value of academic freedom for the faculty and the student body. The University of Illinois is a great university. Its concerns and contributions extend beyond the local to the national and international sphere. It must, of course, operate within the community in which it is located. But if it is to function on the scale and in the manner which it is capable, its top administration and its Board of Trustees must be ready to recognize its maturity, its ability to absorb a few gadflies, and its need for uninhibited freedom of discussion.

Thomas I. Emerson (Law), Yale University, Chairman Robert E. Butts (Philosophy), Bucknell University Harry J. Leon (Classics), University of Texas

\section{The Investigating Committee}

Committee $\mathrm{A}$ on Academic Freedom and Tenure has by vote authorized publication of this report in the $A A U P$ Bulletin: 
David Fellman (Political Science), University of Wisconsin, Chairman.

Members: Robert B. Brode (Physics), University of California at Berkeley; Frances C. Brown (Chemistry), Duke University; Clark Byse (Law), Harvard University; William P. Fidler (English), Washington Office; Ralph F. Fuchs (Law), Indiana University; Bentley Glass
(Biology), The Johns Hopkins University; Louis Joughin (History), Washington Office; Harold W. Kuhn (Mathematics), Princeton University; Walter P. Metzger (History), Columbia University; Glenn R. Morrow (Philosophy), University of Pennsylvania; Paul Oberst (Law), University of Kentucky; C. Herman Pritchett (Political Science), University of Chicago; Warren Taylor (English), Oberlin College.

\section{Part II. "Academic Responsibility"; Statement of the Ad Hoc}

\section{Committee in the Koch Case}

The report submitted to Committee $A$ by the ad hoc investigating committee in the University of Illinois Koch case originally contained a fully developed section en. titled "The Discharge: The Substantive Issues." This section dealt with the standard of "academic responsibility" as set forth in the 1940 Statement of Principles and in the University of Illinois Statutes, and the application of these standards by the University authorities in the Koch case. Necessarily, the ad hoc committee stated in its report its understanding of the standard of academic responsibility, particularly in relation to the Association position that a teacher should be free from institutional censorship when be writes or speaks as a citizen.

Committee $A$ consideration of the report, over a long period of time, revealed a variety of partial agreements, partial differences of emphasis, and partial disagreements with the view of the ad hoc committee on the subject of academic responsibility. There were also differences ap. parent among the members of Committee $A$. The solution reached involves a three-part presentation: Part I (printed supra), a report by the ad hoc investigating committee fully agreed to by both that group and Committee $A$, covering the facts, the procedural issues, other issues, and the present status of academic freedom at the University of Illinois; Part II, a statement by the ad hoc committee on the substantive issues, embodying its views on the validity of the standard of academic responsibility and the application of such a standard in the Koch case; and Part III, a statement approved by a majority of Committee $A$ in reference to Part II and a dissenting statement $b y^{\prime} a$ member of Committee $A$.
Committee $A$ wishes to continue thoughtful study of the standard of academic responsibility. It is indebted to the members of the ad hoc committee in the Koch case for their penetrating analysis of the issues involved; Committee $A$ will also be grateful to individual members of the Association who care to offer either general comment on the standard of academic responsibility, or on its application in the Koch case.

The ad boc committee believes that the substantive issues raised by the Koch case ought to be considered in any disposition of this matter. We appreciate, and hereby take advantage of, the offer of Committee $A$ to state our views on this aspect of the case in the pages of the Bulletin.

There is agreement among all parties that Professor Koch had the right to express his views, on sex mores as well as other subjects, even though his views were offensive or repugnant to others, or contrary to accepted standards of morality. And it seems to be agreed that his right to express such views is not limited by the fact that his publication of them would be prejudicial to the interests of the University in the sense that it would arouse strong protest by alumni, parents, or other members of the community who disagreed with his position. Protection of this right is, of course, fundamental to the existence of academic freedom.

The crucial substantive issue in this case arises out of the position taken by the university that only a "responsible" expression of views is protected under the princi- 
ples of academic freedom, and that Professor Koch's expression here was not "responsible." The University defines this "academic responsibility," as we understand its position, as meaning conformity with the provisions of Section 39(b) of the University of Illinois Statutes and Paragraph (c) of the 1940 Statement of Principles on Academic Freedom and Tenure. We quote Section 39(b) :

In his role as citizen, the faculty member has the same freedoms as other citizens, without institutional censorship or discipline, although he should be mindful that accuracy, forthrightness, and dignity befit his association with the University and his position as a man of learning.

\section{Paragraph (c) of the 1940 Statement reads as follows:}

The college or university teacher is a citizen, a member of a learned profession, and an officer of an educational institution. When he speaks or writes as a citizen, he should be free from institutional censorship or discipline, but his special position in the community imposes special obligations. As a man of learning and an educational officer, he should remember that the public may judge his profession and his institution by his utterances. Hence he should at all times be accurate, should exercise appropriate restraint, should show respect for the opinions of others, and should make every effort to indicate that he is not an institutional spokesman.

The issue raised is one of basic importance to the development of academic freedom in the United States. ${ }^{3}$

The ad boc committee is of the opinion that (1) as applied to a faculty member having definite or indefinite tenure, making public utterances on matters of general concern to the community, the standard of "academic responsibility" is not a valid basis for reprimand, dismissal, or other official discipline; and (2) assuming such a standard to be valid in such a situation, its application in Professor Koch's case does not justify official discipline. We would therefore conclude that, in this respect also, the action of the University in suspending Professor Koch and terminating his contract constituted a breach of the principles of academic freedom.

\section{A. Validity of the Standard of "Academic Responsibility"}

We are dealing here with a member of the faculty having definite tenure under a contract which, at the time of publication of the letter, had more than a year to run. The letter in question was published by Professor Koch in his capacity as a citizen of the community and was addressed to an issue of general interest then under

\footnotetext{
'It should be noted that the position of the Board of Trustees is not altogether free of ambiguity. Thus the Board seems to consider the "content" of the Koch letter as relevant to the question of "responsibility." Furthermore, it is of course not possible here, as elsewhere, to draw a sharp line between substance and form. Nevertheless we believe the issue here to be essentially as we have stated it.
}

discussion in the community. It was not written as a scholarly publication in Professor Koch's field of special competence, a problem with which we are not here concerned. It is our view that, in such a situation, a faculty member should have the same right of expression as any other citizen and that university discipline should not be invoked under any standard of "academic responsibility." Such sanctions as are appropriate in this situation are the unofficial judgment and pressures derived from the basic standards of the academic profession and the intellectual community.

There can be no doubt that the ordinary citizen, addressing himself to a matter of public concern, is not limited by any standard of "responsibility." Apart from the law of libel or similar legal restrictions-which are clearly not applicable here-there is no requirement that the citizen speak with restraint, dignity, respect for the opinion of others, or even accuracy. To impose any such official limitation would effectively cut off any real discussion of controversial issues of either fact or opinion. This is a cardinal principle of freedom of expression. Its classical statement is that of John Stuart Mill, which deserves quotation at some length:

Before quitting the subject of freedom of opinion, it is fit to take some notice of those who say that the free expression of all opinions should be permitted, on condition that the manner be temperate, and do not pass the bounds of fair discussion. Much might be said on the impossibility of fixing where these supposed bounds are to be placed; for if the test be offence to those whose opinions are attacked, I think experience testifies that this offence is given whenever the attack is telling and powerful, and that every opponent who pushes them hard, and whom they find it difficult to answer, appears to them, if he shows any strong feeling on the subject, an intemperate opponent. But this, though an important consideration in a practical point of view, merges in a more fundamental objection. Undoubtedly the manner of asserting an opinion, even though it be a true one, may be very objectionable, and may justly incur severe censure. But the principal offences of the kind are such as it is mostly impossible, unless by accidental selfbetrayal, to bring home to conviction. The gravest of them is, to argue sophistically, to suppress facts or arguments, to misstate the elements of the case, or misrepresent the opposite opinion. But all this, even to the most aggravated degree, is so continually done in perfect good faith, by persons who are not considered, and in many other respects may not deserve to be considered, ignorant or imcompetent, that it is rarely possible, on adequate grounds, conscientiously to stamp the misrepresentation as morally culpable; and still less could law presume to interfere with this kind of controversial misconduct. With regard to what is commonly meant by intemperate discussion, namely invective, sarcasm, personality, and the like, the denunciation of these weapons would deserve more sympathy if it were ever proposed to interdict them equally to both sides; but it is only 
desired to restrain the employment of them against the prevailing opinion: against the unprevailing they may not only be used without general disapproval, but will be likely to obtain for him who uses them the praise of honest zeal and righteous indignation. Yet whatever mischief arises from their use, is greatest when they are employed against the comparatively defenseless; and whatever unfair advantage can be derived by any opinion from this mode of asserting it, accrues almost exclusively to received opinions. The worst offence of this kind which can be committed by a polemic, is to stigmatize those who hold the contrary opinion as bad and immoral men. To calumny of this sort, those who hold any unpopular opinion are peculiarly exposed, because they are in general few and uninfluential, and nobody but themselves feels much interested in seeing justice done them; but this weapon is, from the nature of the case, denied to those who attack a prevailing opinion; they can neither use it with safety to themselves, nor, if they could, would it do anything but recoil on their own cause. In general, opinions contrary to those commonly received can only obtain a hearing by studied moderation of language, and the most cautious avoidance of unnecessary offence, from which they hardly ever deviate even in a slight degree without losing ground: while unmeasured vituperation employed on the side of the prevailing opinion, really does deter people from professing contrary opinions, and from listening to those who profess them. For the interest, therefore, of truth and justice, it is far more important to restrain this employment of vituperative language than the other; and, for example, if it were necessary to choose, there would be much more need to discourage offensive attacks on infidelity than on religion. It is, however, obvious that law and authority have no business with restraining either. ... .

These considerations seem to us fully applicable to the exercise of official sanctions by a university against members of the academic profession. It is true that a faculty member can never completely dissociate himself from the institution to which he belongs. Nevertheless, it is also true that the community now recognizes, or can be educated to recognize, that expressions of individual faculty members on controversial public issues are not to be attributed to the university. Moreover, whatever tarnish rubs off on the university by reason of an immoderate statement of an offensive idea, would hardly be greater than that accruing from a consummately polished, and hence more persuasive, statement of the same idea. Yet it is conceded by all that the latter "burden," if it can be called that, is one the university must bear. We fail to see, therefore, why the university need stand censor over the language and tone of its faculty members, rather than leaving to traditional guild pressures the maintenance of a respectable level of discourse.

On the other hand much harm can come from

\footnotetext{
' John Stuart Mill, On Liberty (Neff ed., 1926), pp. 63-4.
}

application of university sanctions to the manner in which public controversy is carried on by faculty members. The concept of "irresponsibility" is exceedingly vague. Any one of us can easily call to mind statements by our colleagues which might be termed by some as unrestrained, undignified, or lacking respect for the opinion of others. Any serious application of the standard would tend to eliminate or discourage any colorful or forceful utterance. More likely, as Mill observes, the standard would be reserved as a sanction only for expression of unorthodox opinion.

As we read Section 39(b) of the Illinois Statutes, the notion of academic responsibility, when the faculty member is speaking as a citizen, is intended to be an admonition rather than a standard for the application of discipline. That provision declares flatly that "the faculty member has the same freedoms as other citizens, without institutional censorship or discipline," and states the qualification of academic responsibility only as one of which the faculty member "should be mindful."

The 1940 Statement of Principles appears to us ambiguous on this point. On its face Paragraph (c) merely says that the faculty member speaking as a citizen has "special obligations" which he "should remember" and "should" adhere to. On the other hand the legislative history of the provision points somewhat in the other direction. A 1938 draft of the document contained an express statement that the judgment of what constitutes fulfillment of these obligations should rest with the individual; this was eliminated in the 1940 Statement. ${ }^{\text {s }}$ An interpretation adopted at the conference of representatives of the AAUP and the Association of American Colleges, which approved the 1940 Statement, reads:

3. If the administration of a college or university feels that a teacher has not observed the admonitions of Paragraph (c) of the section on Academic Freedom and believes that the extramural utterances of the teacher have been such as to raise grave doubts concerning his fitness for his position, it may proceed to file charges under Paragraph (a) (4) of the section on Academic Tenure. In pressing such charges the administration should remember that teachers are citizens and should be accorded the freedom of citizens. In such cases the administration must assume full responsibility and the American Association of University Professors and the Association of American Colleges are free to make an investigation.

The first sentence of this interpretation appears to elevate the "special obligations" of the faculty member speaking as citizen to a standard of discipline to be

\footnotetext{
${ }^{5}$ See Richard Hofstadter and Walter P. Metzger, The Development of Academic Freedom in the United States (1955), p. 487.
} 
applied by the university administration. But the next sentence-stating that in such proceedings the faculty member "should be accorded the freedom of citizens" -is squarely inconsistent. It is true that, outside an academic freedom context, the "freedom of citizens" would not protect a citizen from economic penalties, but only from legal sanctions. But in an academic freedom context university discipline is the equivalent of legal sanction. Hence to say that faculty members should have the same "freedom" as citizens must mean that university discipline cannot be applied where legal sanctions would not be. Otherwise the sentence would seem to have no meaning. In short the "interpretation" appears to be a compromise which actually left the matter unresolved.

It is hard to believe that the 1940 Statement of Principles means that faculty members are subject to discipline for infraction of such vague "admonitions" as being "accurate," exercising "appropriate restraint," or showing "respect for the opinions of others." In any event, for the reasons we have given, we believe that the principle as we have construed it is the sound one and the only one consistent with the attainment of acedemic freedom.

\section{B. Application of the Standard of "Academic Respon-} sibility" in This Case

Assuming the validity of the standard of "academic responsibility," the ad boc committee is of the view that application of the standard in this case does not justify disciplinary action by the University.

As we understand the decision of the Board of Trustees, it holds that the publication of the letter constituted a breach of academic responsibility on two principal grounds: (1) that Professor Koch intended to and did encourage and espouse immoral and illegal acts on the part of students at the University; and (2) that the letter was not a reasoned statement but was intemperate, undignified, and lacking in respect for the opinions of others. The Board also urges at one point a third ground: (3) that, although Professor Koch inserted his academic title following his signature, he "made no effort to make plain in his letter that it contained only his individual views and that he was not writing it as a spokesman for the University." We consider these points in order.

1. Encouragement of immorality and illegality. There was no evidence before the Board of Trustees other than the letter itself, that Professor Koch "intended" to encourage immoral or illegal acts on the part of students. Before the Senate Committee on Academic Freedom Professor Koch stated he had no such intention. The issue must therefore be considered on the basis of the wording of the letter.

Every forceful expression of an idea is an encouragement to act upon it. As Justice Holmes has said,
"Every idea is an incitement." To say that a faculty member may express unorthodox ideas, but is violating academic responsibility if his ideas encourage action, renders the right of expression meaningless. Perhaps a line must be drawn somewhere, although we do not see any satisfactory way of drawing it short of the point where expression becomes an illegal solicitation to crime, a point certainly not reached here. But the prohibition surely cannot extend to everything which falls within the term "encouragement" or "espousal." And we see nothing in the letter which constituted encouragement or espousal beyond what naturally adheres to a vigorous presentation of the ideas that Professor Koch was endeavoring to put forward.

Counsel for the University argues that Professor Koch was challenging students to act when he said that college students seemed to him to be "acting with remarkable decorum, and surprising meekness, if they do no more than neck at their social functions"; and that such behavior "indicates an extreme degree of brainwashing by our religious and civil authorities." This is strong language. But it does not seem to us to carry "encouragement" beyond the bounds of vigorous expression of an idea. Actually, Professor Koch's conclusion was not couched in terms of urging but in terms of condoning under certain circumstances: "there is no valid reason why sexual intercourse should not be condoned among those sufficiently mature to engage in it without social consequences and without violating their own codes of morality and ethics."

We would conclude, therefore, that a finding of academic irresponsibility on grounds of encouragement and espousal in this situation amounts to little more than, through a back-door route, foreclosing expression of the ideas themselves.

2. Intemperateness. The Board of Trustees' second major ground for finding a breach of academic responsibility goes to the form and tone of the letter. This conclusion rests upon a number of subsidiary points:

(a) The Board found that Professor Koch's letter "was not a reasoned statement, marshalling evidence in support of views held by him." If the letter be taken as a scientific essay on the problem of sex mores the objection might have some weight. But plainly the letter was not so intended. Like the letter to which it was a response, it was a comment and expression of views upon a broad problem under discussion on the campus. As such, it seems to include as much reasoning as letters of this nature customarily do. In any case, it is difficult to see how the question of the reasonableness of a view is related to the question of a person's freedom to express it. Clearly Professor Koch believed the views to which he gave expression, and the letter gives every indication 
that he stood ready to discuss at length the evidential merits of his position.

(b) The Board also found that the letter used "overstatement and ridicule." These techniques are frequently employed in academic and public discussions, often by our most respected writers. The success of the techniques, as might be expected, varies, and Mill's position quoted earlier states the general rule of such variation: overstatement and ridicule are normally acceptable when used against unpopular views, normally unacceptable when used against popular ones. Clearly such standards must be rejected in the interests of genuine freedom of expression. In any event Professor Koch's letter does not seem to go beyond customary limits in the use of overstatement and ridicule.

(c) Another Board objection is that Professor Koch "denounced society as depraved [and] condemned as inhumane and obsolete the widely accepted moral standards derived from the Christian code of ethics and the commonly accepted moral standards then prevailing in the community." Many scholars, more profound than Professor Koch, have similarly denounced existing social patterns and condemned current moral standards. Moreover, the Board's objection here goes to the ideas presented, not to their form. It perhaps ought to be emphasized in this connection that if a great liberal university is to make its maximum long-term contribution to society both locally and beyond its peculiar environment, one of its chief roles must be that of critic of society. Both the life of a university and the life of the society of which it is a part depend upon successful expression of this role. A great university is not a shepherd the members of whose flock are expected to confine themselves to "commonly accepted ideas"; ideally, it is an enlightened and lively center of investigation and controversy. If it falls too far short of this ideal, the very concept of academic freedom in such an institution becomes degraded into meaninglessness.

(d) The next objection is that Professor Koch "castigated those who might disagree with his conclusions as outrageously ignorant," and thus failed to show "respect for the opinions of others." But Professor Koch's disagreement with the opinions held by others does not seem to be of any different scale or temper from what one frequently finds expressed in public controversy and often academic controversy. Again Mill's position supplies the pragmatic maxim: we do not object to the castigation as "outrageously ignorant" of those holding views contrary to our own views. The implication seems clear enough that in this conclusion also the Board intrinsically appeals to the unacceptability of the ideas themselves, not to Professor's Koch's supposedly intemperate manner of expressing them.

(e) The Board further finds that the language of the letter was not in keeping with proper standards of "temperateness" and "dignity." Again, if one puts aside the substantive ideas expressed, we are unable to see wherein the letter varies in tone from frequent letters to the editor published by faculty members and others. The standard of responsibility applied in this way would make many of our more colorful and indeed educationally effective academicians subject to discipline, leaving the field to the dull and the innocuous.

(f) Finally, the Board states that the contents of the letter were not "accurate." But the letter is largely an expression of an opinion which some hold to be sound and many others do not. The test of accuracy has no real application to such circumstances. This is especially the case since much that Professor Koch contends in his letter will be scientifically controversial for some time to come. The test of a controversial theory extends beyond the question of the accuracy of its statement. The Copernican astronomy, when first stated, was not accurate in all particulars, but it would have been the height of folly to restrain its public expression for that reason.

Generally speaking, it seems clear to us that, had the letter dealt with any subject other than sex mores, religion, or some other acutely sensitive area, its language and tone would have passed unnoticed. We do not believe that a faculty member writing on these subjects should be held to higher standards of responsibility than one writing on less controversial topics. In any event we are convinced that fundamentally the objections of the Board of Trustees are directed against the "offensive and repugnant" views expressed, rather than the style of composition. This would appear to have been the reaction also of President Henry, as conveyed in his letter of April 7. Once one excludes from consideration the "offensive" nature of the substantive ideas in Professor Koch's letter, as it is conceded the principles of academic freedom require, the finding of a breach of academic responsibility because of language and tone seems to us wholly untenable.

3. Professor Koch as institutional spokesman. The Board of Trustee's finding that Professor Koch, by giving his academic title along with his signature, did not make it clear that he was not an institutional spokesman, appears to us without merit. Surely no reader could have thought that Professor Koch was expressing the University's point of view. Moreover, it was not exceptional for a faculty member to identify himself in writing letters to the editor, and the University did not object to this practice. In this instance the use of the title actually made little practical difference as Professor Koch could readily be identified from the faculty directory by most of the readers of The Daily Illini.

Thomas I. Emerson, Yale University, Chairman

Robert E. Butts, Bucknell University

Harry J. Leon, University of Texas 


\title{
Part III. "Academic Responsibility"; Comments by Members of
}

\author{
Committee A Incident to Consideration of the Koch Case
}

Committee A believes that it should be perfectly clear to any fair-minded observer, from the ad hoc committee's account of the facts of this case, that Professor Koch was denied academic due process by the Administration of the University of Illinois. Professor Koch was discharged by President Henry without notice of charges or a hearing, and then was given a hearing in an environment strongly colored by the President's discharge action and by widespread publication of the letter in which the discharge was announced. It was extremely unfortunate, and damaging to Professor Koch, that during the whole period following publication of President Henry's initial letter of discharge the issue of confidence in the President's judgment cast its shadow over all other issues. Under these circumstances Professor Koch's procedural rights were irretrievably compromised. Another hearing cannot mitigate the error, because a fair hearing cannot be held so long as the essentially irrelevant but powerful issue of confidence in the President remains in the picture.

In Part II of this report the ad hoc committee spells out its position on the substantive issue of "academic responsibility." These are the views of able men dedicated to infellectual freedom, and they are entitled to great respect. Therefore, Committee A has authorized their publication. They cannot, however, be accepted by Committee A.

Academic responsibility is admittedly very difficult to define. Nevertheless, we can hardly expect academic freedom to endure unless it is matched by academic responsibility. The question here at issue is whether academic responsibility is necessarily and entirely a concept which a faculty member applies to his own conduct by his own standards, or whether a faculty or administrative body can properly impose sanctions on a faculty member for a violation of what it considers to be the standard of academic responsibility. Whatever the answer, the primary source of any decent level of academic responsibility will, of course, always be the individual conscience.

A university faculty and administration have a legitimate interest in the maintenance of proper standards of faculty responsibility on the part of all members of the academic community. Are "traditional guild pressures," as the ad hoc committee holds, all that should be permitted in order to maintain such a standard? The borderline between expression of views and the condoning, encouragement, or incitement of improper acts is tenuous and difficult to draw, but situations do occur in which a distinction must be made. For a judgment of that kind, recourse should be had in the first instance to a committee of the faculty. Both traditionally and practically, it is the duty and within the particular competence of the faculty to make the distinction and to recommend any appropriate action. Such judgment and action were substantially accomplished in this case by the committee of the University of Illinois Senate, even though administrative prejudgment preceded and over-ruling followed the faculty committee hearing, findings, and conclusions.

The legislative history of the 1940 Statement of Principles demonstrates that the views expressed by the authors of the report in their supplementary statement, Part II, relating to the concept of academic responsibility, did not prevail when the 1940 Statement was formulated.

The 1925 Conference Statement on Academic Freedom and Tenure contained a provision for submitting "to an appropriate body of the faculty" a case involving the extramural utterances of a teacher which "raise grave doubts concerning his fitness for his position." During the joint committee discussions with representatives of the Association of American Colleges (the AAC), which preceded the formulation of the 1940 Statement, the AAUP committeemen argued that this provision should be eliminated, and in its stead there should be a clause conceding that the judgment "should rest with the individual" as to what constitutes propriety of extramural utterance. The substitute was rejected by the AAC representatives who argued that individual judgment on this question was not sufficient, and that charges relating to allegedly improper utterance should be heard by some impartial extra-institutional tribunal rather than by a committee of colleagues of the accused.

In response to the AAC objections, General Secretary Himstead replied that the administration always had the right, when it believed that professors went too far in their extramural utterances, to bring charges under the rules of tenure. In taking this position, which proved acceptable to the AAC representatives, the AAUP conceded a defeat for the proponents of complete guild autonomy and individual judgment in this area. The joint committee recorded its consensus on this question in a footnote "Interpretation," quoted earlier by the 
authors of this report (page 37). The ad boc committee correctly judges the "Interpretation" to be a compromise, but Committee $\mathrm{A}$ cannot agree that the issue in question actually was left unresolved, as the ad boc committee concludes. In the light of Committee A's understanding of the 1940 Statement, together with the legislative history of the document and its "Interpretation," the Committee disagrees with the conclusion of the authors of the report that "the notion of academic responsibility, when the faculty member is speaking as a citizen, is intended to be an admonition rather than a standard for the application of discipline." In accepting this standard, however, Committee A understands by "application of discipline" only such action as may properly derive from the use of academic due process-i.e., the presentation of charges, and a subsequent faculty committee hearing resulting in a judgment.

The policy of permitting disciplinary action to be initiated by the administration is not likely to result in impairment of free utterance by faculty members if under established academic traditions and procedures the initial and primary judgment of an accused individual's action rests with his colleagues. In the words of the 1915 Declaration of Principles, "in matters of opinion, and of the utterance of opinion, ... . [lay governing] boards cannot intervene without destroying, to the extent of their intervention, the essential nature of a university -without converting it from a place dedicated to openness of mind, in which the conclusions expressed are the tested conclusions of trained scholars, into a place barred against the access of new light, and precommitted to the opinions or prejudices of men who have not been set apart or expressly trained for the scholar's duties."

Committee A recognizes that institutions may abuse the power to discipline faculty members for established breaches of academic responsibility, but the possibility that power may be abused is not a proper ground for denying its existence. The remedy is, instead, insistence on proper procedural safeguards, a highly significant role for the faculty in the exercise of the power, and a vigilant oversight by this Association. Oversight by the Association in this sensitive area will, of course, include examination and review of faculty as well as administrative action.

Committee A concludes that the Administration of the University of Illinois did not err in proceeding on the assumption that a violation of academic responsibility on the part of a faculty member fell within the disciplinary powers of the institution. Committee $A$ also concludes that the University of Illinois Senate Committee on Academic Freedom had jurisdiction in this case.

Whether one agrees with the Illinois Senate Committee that Professor Koch violated proper standards of academic responsibility, and therefore should have been reprimanded, or with the ad hoc committee that there was no violation of academic responsibility, it is clear to Committee A that the sanction of discharge was outrageously severe and completely unwarranted.

Committee $\mathrm{A}$ does not conceive it to be its function to decide independently whether the ad boc committee or the Illinois Senate Committee is correct in its assessment of Professor Koch's action. Reasonable minds dedicated to intellectual freedom could-and do-differ on this issue. The important point is not that there are differences of opinion concerning the question whether Professor Koch's action warranted imposition of the sanction of reprimand or whether his action did not justify imposition of any sanction whatsoever. The crucial fact is the unanimous agreement of the Illinois Senate Committee, the ad hoc committee, and Committee $\mathrm{A}$ that Professor Koch should not have been discharged.

The following members of Committee $A$ approve Part III, the foregoing comments, for publication: David Fellman (Political Science), University of Wisconsin, Chairman; Frances C. Brown (Chemistry), Duke University; Clark Byse (Law), Harvard University; William P. Fidler (English), Washington Office; Ralph F. Fuchs (Law), Indiana University; Bentley Glass (Biology), The Johns Hopkins University; Louis Joughin (History), Washington Office; Paul Oberst (Law), University of Kentucky; C. Herman Pritchett (Political Science), University of Chicago, Professor Glenn R. Morrow (Philosophy, University of Pennsylvania), a member of the Committee during the period in which consideration was given to the report of the investigating committee, although not now a member, also approves.

Professor Warren Taylor (English), Oberlin College, a present member of the Committee, dissents. Professor Walter P. Metzger (History), Columbia University, a present member of the Committee asks to be recorded as not voting. Professors Richard P. Adams (English), Tulane University, Fritz Machlup (Economics), Princeton University, and John P. Roche (Political Science), Brandeis University, present members of the Committee did not participate in consideration of the case. Professors Robert B. Brode (Physics), University of California, and Harold W. Kuhn (Mathematics), Princeton University, members of the Committee during the period in which consideration was given to the report of the investigating committee, although not now members, dissent; Professor Brode concurs with Part II, the statement of the ad hoc committee.

Professor Ralph F. Fuchs asks that the following footnote to the Committee A comments, Part III, be appended:

"Mr. Fuchs wishes to supplement his concurrence by recording his view that the statement of Committee $\mathrm{A}$ should emphasize that institutional discipline for an 
utterance allegedly violating the 'standard of academic responsibility' in the 1940 Statement of Principles cannot validly call in question the facts or opinions set forth by a faculty member. A violation may consist of serious intemperateness of expression, intentional falsehood, incitement of misconduct, or conceivably some other impropriety of circumstance. It may not lie, however, in the error or unpopularity, even though gross, of the ideas contained in an utterance."

Professor Warren Taylor asks that the following dissent (in which Professor Brode concurs) be appended:

As a member of Committe A, I am unable to agree with the interpretation of the Association's 1940 Statement of Principles which is stated in Part III of the Koch-Illinois report. The issue, as I see it, is on what grounds an administration may justly bring charges against a teacher for expressing his opinions, charges which, when substantiated by due process, may justify suspension or dismissal. The only ground for such disciplinary action that I can find in the 1940 Statement is unfitness to teach. I do not believe that the 1940 Statement supports those of my colleagues who, in Part III, find in it a new standard, a standard of "academic responsibility," which they call, using the phrase from the ad boc committee's report, "a standard of discipline." This means that a teacher judged by due process to have violated the supposed standard of "academic responsibility" in the expression of his opinion may, for that statement of opinion, be justly dismissed.

This erroneous interpretation of the 1940 Statement presupposes but does not enumerate special standards for the discipline of teachers in the expression of their opinions which do not apply to all other citizens. The 1940 Statement, however, says explicitly and later repeats the principle that teachers are citizens, and in the expression of their opinions, should be accorded the same freedom accorded by law to all other citizens. Selfrestraint is the individual teacher's own problem. By. law, in the expression of his opinions, the teacher is no less free than other citizens.

All citizens, including professors, express their opinions publicly at their own peril. Judgments of their utterances will vary as greatly as those who judge them. Anyone who opens the windows of his mind cannot be too surprised if some throw stones. That is in the domain of public discourse, without penalties to enforce conformity. Freedom of speech is not a one-way flow of discourse. It includes freedom to disagree and to disapprove, also without penalty. A university faculty is free to disagree with and to disapprove the opinions of a teacher. But to pillory any citizen, including a professor, because he has stated an unpopular or heterodox view not proscribed by law, is at once, in that degree, to convert a free society into a totalitarian society.
Part III does not define the supposed standard of "academic responsibility." It does not show precisely how "admonitions," which are not in themselves standards, are transformed into standards. It does not clarify this new concept by giving relevant particulars: specific instances and specific offenses. It does not answer the pertinent question: "What specific expression of opinion by a teacher violates the standard of academic responsibility and thereby warrants suspension or dismissal?"

This new standard was framed, I believe, in forgetfulness of Occam's razor. Its proponents have postulated as existing a test for discipline which was not earlier known to exist. "Academic responsibility" in the expression of opinion as "a standard of discipline" is not mentioned as ground for adverse action in the special report of 1956, "Academic Freedom and Tenure in the Quest for National Security" (AAUP Bulletin, Spring, 1956, pp. 57-8). They have multiplied tests unnecessarily and have not validated new formulations. I am unable to find in the 1940 Statement either an implied or an explicitly stated standard of "academic responsibility" which may be cited to restrain the teacher as citizen in the expression of his opinions. Consequently, I am unable to agree with those members of Committee $A$ who conclude that, on the basis of the 1940 Statement, "the Administration of the University of Illinois did not err in proceeding on the assumption that a violation of academic responsibility on the part of a faculty member fell within the disciplinary powers of the institution."

In its support of basic principles and procedures which seek to assure academic freedom and tenure for the profession, the Association has never denied that educational institutions have the right and power to appoint and dismiss teachers. The Association has never set up criteria for appointments. It has never questioned that established dereliction of duty and professional incompetence are valid tests for dismissal. These two, singly or in combination, have, in practice, for the Association, constituted unfitness to teach. Such unfitness, the Association has held and now holds, must be established by due process. There is, historically, one test for dismissal: demonstrated unfitness to teach.

The 1940 Statement of Principles says nothing about a special standard of "academic responsibility" in a teacher's expression of his opinion which, when violated, may lead to discipline. It says that teachers as citizens should be accorded the freedom of citizens. It reminds them, as admonition, and not as standards of discipline, that all teachers who state their opinions publicly, as do all citizens, do so at their own peril and that teachers may best protect themselves and their views by being accurate, exercising restraint, and respecting the opinions of others. The 1940 Statement sets up no appropriate penalties for inaccuracy, disrespect, or a lack of restraint. 
It labels its precautions explicitly as "admonitions," not as "standards of discipline." The appended interpretation then spells out a procedure for administrators who believe that a professor's extramural utterances raise doubts concerning his fitness for his position. For the 1940 Statement to have any consistency at all and freedom from contradiction this can only mean that the teacher's public expression of his opinions may become ground for moving towards his dismissal when and only when those opinions reveal unfitness to teach: what may be established as dereliction of duty and professional incompetence. The single standard of fitness to teach remains. A second standard of "academic responsibility" does not actually emerge.

In seeking to multiply tests for the expression of opinion Committee $\mathrm{A}$ has already run into the same kind of difficulties encountered by the most eminent jurists who have faced the question. Debate over Justice Holmes's test of "clear and present danger" continues. And Justice Brandeis's tightening of the test in 1927 to make the danger apprehended by the words so imminent that catastrophe might befall before full discussion could occur has not settled the matter, finally, any more than Judge Hand's "gravity of evil." To speak of "academic responsibility" as a standard or test for dismissal because a teacher has expressed an unpopular opinion without anchoring it to unmistakable particulars is to waver on a floating bog of semantics.

In my opinion, Committee A should not seek to multiply needless standards, too general and too abstract to be useful in examining cases. The Association actually possesses no codification of alleged violations of freedom of speech. Nor should it seek one. When an administrator believes that a teacher's utterances actually reveal an unfitness to teach, he may file charges. "In pressing such charges the administration should remember that teachers are citizens and should be accorded the freedom of citizens. In such cases the administration must assume responsibility" and the Association is "free to make an investigation" of that administration's findings and action. That is what the appended interpretation to the 1940 Statement actually says. The entire statement is free from any listing of specific offenses and penalties in the expression of opinion.

That is entirely appropriate for two reasons. In considering cases, Committee $\mathrm{A}$ has to view and review each on its own merits. Formulae, precedents, bureaucratic decree, and abstract essences are all unavailing. The real distinction achieved over the past half century by Committee A stems in large measure, not from its multiplying standards, but rather from its exacting examination, in its search for fairness to all, of each case on its own merits. The second reason is that neither the Association nor a university possesses legislative and judicial power to restrain the citizen's expression of opinion. Misconstruing their function is a serious error that should be constantly corrected. In a free society, the state itself restrains only those utterances which threaten its very existence. Beyond legal restraints, the state has no favored opinions. In a free society, neither the state nor educational institutions possess the power to penalize or coerce conformity in the opinions of teachers as citizens. The university in a free society, as a free institution, has no favored political, economic, or sectarian opinions: Republican or Democratic; Keynesian or classical; Protestant, Catholic, non-believer, Moslem, Jew, or Hindu. The province of a free university is to make opinions and arguments known and to supply students with the knowledge and competence by which all opinions and arguments may be judged.

To interpret the 1940 Statement of Principles, following the opinion expressed in Part III, as setting up in the exercise of free speech a special standard of "academic responsibility" for teachers, not binding on other citizens, as a standard for suspension or dismissal is to open a Pandora's box of all the coercive and compulsive crusades of sectarian, political, and economic pressure groups together with consequent attempts at dismissal by administrators who are unable to resist the public pressure engendered by such groups whose causes often contain more heat than light.

The Association, I am confident, has been wise in not actually undertaking to set up and attempt to defend a standard of "academic responsibility" as a standard of discipline or to sanction dismissal for the expression of opinion. For history is strewn with the victims of "standards of discipline" in the expression of opinion from Socrates and Jesus and Joan of Arc to the victims of the Alien and Sedition Laws of 1798, the Espionage Act of 1917, and the Sedition Act of 1918 on to the victims of totalitarian coercion of opinion during this century. There is no need now to seek or to create a new standard to silence teachers. To fire a teacher for his utterances the administrator cannot rely on such an ambiguous test as that of "academic responsibility." The opinions of a teacher as citizen are not enough to justify termination. The administrator will have to establish proof that beyond the utterance lies unfitness to teach: professional incompetence, dereliction of duty. Freedom of speech for all remains one basic principle of free societies. Freedom of speech for all remains one basic American principle. The Association remains an American association.

WARREN TAYLOR 